\title{
PERAN KOPING RELIGIUS DAN KESEJAHTERAAN SUBJEKTIF TERHADAP STRES PADA ANGGOTA BINTARA POLISI DI POLRES KEBUMEN
}

\author{
Amalia Juniarly \\ M. Noor Rochman Hadjam \\ Fakultas Psikologi Universitas Gadjah Mada Yogyakarta \\ Email: lia_uii@yahoo.com
}

\begin{abstract}
This study aims to determine the role of religious coping and subjective well-being to stress on the non-commissioned members of the police at the police resort Kebumen. Research subjects were the non-commissioned members of the Sabhara police force at police resort Kebumen and muslims. Data collection methods used scale. The results were analyzed using partial correlation analysis. Coefficient correlation between stress and religious coping of -0.517 with $p=0.000(p<0.01)$, while the coefficient of correlation with subjective well-being of -0.309 with $p=0.022$ ( $p>0.01$ ). This suggests that there was a significant negative correlation between religious coping, subjective well-being and stress. The higher religious coping and subjective well-being levels, the lower the stress levels. In other words, stress can be predicted based on religious coping and subjective well-being. Thus, the hypothesis accepted.
\end{abstract}

Keywords: Religious Coping, Subjective Well-Being, Stress

Setiap manusia selalu memiliki kebutuhan-kebutuhan pokok yang bersifat fisik, psikis dan sosial. Begitupun dengan polisi. Ketegangan-ketegangan dan konflikkonflik batin polisi akan timbul apabila kebutuhan-kebutuhan hidup terhalang untuk dipenuhi. Jika polisi terus-menerus dihalangi kebutuhannya, maka hal ini akan membuat orang tersebut menjadi frustrasi dan stres.

Tidak dapat dipungkiri hampir semua orang dalam kehidupanya pernah mengalami stres, misalnya stres dalam pekerjaan. Salah satu dari kebanyakan pekerjaan yang penuh dengan stres yaitu bekerja sebagai pelaksana hukum (Yusuf, 2009). Menurut Selye (Constan, 1991), pekerjaan polisi adalah pekerjaan yang paling menimbulkan stres di Amerika. Sementara Boyce (2006) berpendapat bahwa stres merupakan bagian yang tidak terpisahkan dari pekerjaan polisi.

Pekerjaan polisi penuh dengan stres tingkat tinggi karena merupakan salah satu pekerjaan yang secara terus-menerus berhadapan dengan bahaya fisik dan mempertaruhkan hidupnya setiap waktu. Stres yang terjadi pada polisi berbeda dari stres orang-orang pada umumya karena biasanya mereka menghadapi situasi yang berbeda dari orang kebanyakan, yaitu mereka harus menghadapi suatu peristiwa atau kejadian kritis dan cenderung abnormal yang terjadi secara terus-menerus dalam pekerjaan mereka, sehingga pada akhirnya dapat membuat mereka menjadi stres (Federal Anti-Terrorism Supplemental Grant, 2010). Menangani kasus kejahatan yang berlangsung secara cepat, serangan fisik, dan rutinitas di pemberhentian lalu lintas adalah contoh ancaman fisik yang menimbulkan stres setiap hari. Selain itu, adanya kejadian yang genting, seperti penembakan, bencana besar-besaran, kekerasan dan kejahatan adalah peristiwa yang dapat membuat polisi menjadi tertekan (stres) karena ini menjadi pengalaman yang tidak pernah dialami oleh penduduk lainnya (Boyce, 2006). Tuntutan yang besar terhadap kemampuan mental, emosional dan fisik pada polisi ini sering menjadi stres bagi mereka (Huda, 2003).

Ada beberapa gejala stres pada polisi menurut Boyce (2006), yaitu gangguan tidur, terutama insomnia dan mimpi buruk, depresi, kecemasan, paranoia, ketakutan, dan panik. Selain itu, petugas sering putus asa dan berharap untuk dapat mengelola emosi mereka dengan beralih ke alkohol atau menggunakan obat-obatan terlarang, lekas marah, perubahan pola makan, pikiran terganggu, perasaan bersalah, kurangnya konsentrasi, terjadinya penyakit fisik, seperti sakit kepala, perut, masalah usus, penyakit kulit, ketegangan 
otot, kelelahan dan kegelisahan juga tandatanda fisik dari stres. Sementara sinisme, ketidakhadiran, kelelahan, pensiun dini, dan pengunduran diri juga hasil dari stres kerja pada polisi.

Stres kerja Polisi terutama terjadi pada para Bintara. Bulan April 2010 istilah Samapta diganti menjadi Sabhara. Sabhara adalah kepanjangan dari Samapta Bhayangkara dan sebagian besar anggota polisi di satuan Sabhara berada pada posisi bintara. Menurut Subiansauri (2010), bintara merupakan akar dari polri yang berada di lapangan, dengan demikian merekalah yang terjun langsung dalam semua kegiatan pengamanan di masyarakat. Namun sayang, dari pengamatan selama ini, rata-rata kesejahteraan prajurit Polri sangat memprihatinkan, dalam arti di bawah garis kebutuhan, khususnya ditingkat bintara dan tamtama. Rata-rata gaji yang diterima hanya cukup untuk memenuhi kebutuhan keluarga dalam dua minggu. Belum lagi adanya pemotongan gaji dengan alasan untuk sumbangan atau dipaksa mencari setoran / sumbangan dan sebagainya (Kunarto \& Tabah, 1995). Menurut Ng, Diener, Aurora dan Harter (2008), orang yang tidak dapat memenuhi kebutuhan dasar mereka atau hidup dalam kondisi sosial ekonomi yang buruk, mungkin mengalami perasaan stres.

Boyce (2006) menambahkan bahwa menangani kasus kejahatan yang berlangsung secara cepat adalah contoh ancaman fisik yang menimbulkan stres setiap hari. Bekerja patroli juga merupakan rutinitas, dan merupakan tugas yang membosankan, tetapi polisi tetap dituntut untuk waspada karena potensi bahaya yang tidak terduga bisa datang sewaktu-waktu. Penelitian Berg, Hem, Lau, dan Ekeberg (2006) mendukung pernyataan di atas. Hasil penelitian Berg dkk (2006) menunjukkan bahwa polisi di Norwegia memiliki tingkat masalah kesehatan muskuloskeletal terutama yang berhubungan dengan frekuensi tekanan kerja dan kurangnya dukungan. Juga cedera di saat bekerja yang sering dikaitkan dengan masalah kesehatan. Ini menunjukkan bahwa pekerjaan rutin polisi setiap hari serta tugas operasional mereka harus dipertimbangkan dalam menilai stres pekerjaan dan kesehatan polisi.

Menurut Folkman dan Moskowitz (2000), stres berhubungan luas dengan hal negatif, seperti depresi, kecemasan, gejala fisik, penyakit, dan bahkan kematian di kasus- kasus ekstrim. Sementara menurut Diener dan Lucas (Compton, 2005), individu yang memiliki tingkatan kesejahteraan subjektif yang tinggi, akan menunjukkan perasaan yang sangat bahagia, sangat puas dengan hidupnya dan punya pengalaman kecemasan yang rendah. Dengan kata lain, apabila tingkatan kesejahteraan subjektif seseorang tinggi, maka orang itu tidak akan mudah mengalami stres.

Diener, Oishi dan Lucas (2003), menyatakan bahwa kesejahteraan subjektif adalah evaluasi secara emosi dan kognitif yang dilakukan seseorang terhadap kehidupannya, termasuk apa yang disebut oleh orang awam dengan kebahagiaan, kedamaian, rasa bermakna dan kepuasan hidup. Bidang kesejahteraan subjektif terdiri dari analisis ilmiah tentang bagaimana orang mengevaluasi kehidupan mereka-baik di saat ini dan untuk waktu yang lebih lama. Evaluasi ini termasuk reaksi emosional terhadap suatu peristiwa, suasana hati mereka, dan bentuk penilaian mereka tentang pemenuhan kepuasan hidup mereka.

Menurut Argle, Myers, dan Diener dkk (Compton, 2005), ada enam variabel inti yang menjadi prediktor terbaik bagi kebahagiaan dan kepuasan dalam hidup, setidaknya di budaya industri Barat, yaitu harga diri, pengendalian yang dapat diterima, sifat terbuka, optimisme, hubungan sosial yang positif serta pemahaman tentang arti dan tujuan. Prediktor lain yang mempengaruhi kebahagiaan dan kepuasan dalam hidup adalah penyelesaian konflik dalam diri atau rendahnya kecemasan dalam diri individu.

Seperti yang diuraikan di atas, salah satu prediktor kebahagiaan dan kepuasan dalam hidup adalah adanya pengendalian yang dapat diterima. Kemudian muncul kontradiksi mengenai pengendalian sebagai sebuah faktor dalam kesejahteraan subjektif datang dari agama. Orang yang religius percaya bahwa Tuhan memiliki kendali utama dalam hidup mereka. Slogan dari Perang Dunia ke-2 adalah "Tuhan adalah co-pilot saya" dan "Bukan kehendakku melainkan kehendak-Mu" adalah contoh dari tempat pengendalian eksternal yang menuju kepada kesejahteraan yang lebih baik. Dengan demikian, walaupun dalam keadaan yang penuh tekanan, individu dengan tingkat kesejahteraan subjektif yang tinggi akan dapat melakukan adaptasi dan coping lebih efektif terhadap keadaan tersebut sehingga dapat merasakan kehidupan yang 
melibatkan agama dalam menyelesaikan masalahnya (Compton, 2005).

Setidaknya ada enam faktor yang mendukung hubungan antara agama dan kesejahteraan, yaitu agama memberikan dukungan sosial, agama membantu mendukung gaya hidup sehat, agama membantu meningkatkan integrasi kepribadian, agama dapat meningkatkan generativity, agama menyediakan strategi coping yang unik dan menyediakan rasa makna dan tujuan. Penelitian Pargament, Smith, Koenig dan Perez (1998) tentang agama dan orientasi strategi coping menemukan strategi yang digunakan orang untuk menghadapi stres dan kesulitan dalam hidup. Orang yang religius dan memiliki strategi coping akan mampu menghadapi stres ataupun depresi dalam hidupnya.

Penelitian George dkk (Compton, 2005) menyarankan kepercayaan agama, keyakinan dan kegiatan keagamaan sebagai pencegah terhadap stres. Sementara penelitian Koenig dkk (Marsella, Wong \& Wong, 2006) menemukan bahwa koping religius(relegious coping) berhubungan dengan pengurangan stres dan perbaikan kesehatan mental lainnya. Menurut Koenig dkk (Ano \& Vasconcelles, 2005), koping religius didefinisikan sebagai penggunaan keyakinan keagamaan atau perilaku untuk memfasilitasi pemecahan masalah dan mencegah atau mengurangi konsekuensi negatif dari keadaan emosional kehidupan yang penuh stres.

Banyak studi telah menemukan bahwa koping religius biasanya berhubungan dengan hasil positif terhadap peristiwa-peristiwa hidup yang penuh stres. Misalnya, Pargament dkk (Ano \& Vasconcelles, 2005) menemukan bahwa upaya koping religius melibatkan kepercayaan dalam mencintai Tuhan, pengalaman tentang Tuhan sebagai mitra pendukung, keterlibatan dalam ritual keagamaan, dan pencarian spiritual dan dukungan pribadi secara signifikan terkait dengan hasil yang lebih baik, seperti kesehatan mental dan pertumbuhan rohani.

Berdasarkan hal di atas, peneliti ingin membuktikan bahwa ada peranan koping religius dan kesejahteraan subjektif terhadap stres pada anggota bintara polisi di Polres Kebumen. Apabila memang terbukti, penelitian ini diharapkan dapat memberikan manfaat bagi anggota polisi dan Kepolisian Republik Indonesia untuk mengatasi dan mengurangi tingkat stres dengan cara meningkatkan penggunaan koping religius dan kesejahteraan subjektif pada anggotaanggotanya.

Nevid dkk (2002) menyatakan bahwa stres menunjukkan adanya tekanan atau tuntutan yang dialami individu agar dapat beradaptasi atau menyesuaikan diri. Sementara menurut Folkman dan Moskowitz (2000), stres berhubungan luas dengan hal negatif, seperti depresi, kecemasan, gejala fisik, penyakit, dan bahkan kematian di kasus-kasus ekstrim. Folkman dan Moskowitz (2000) kemudian mendefinisikan stres sebagai konsep yang berasal dari situasi eksternal, seperti peristiwa besar dalam hidup atau pertengkaran seharihari. Sementara menurut Hawari (2008), stres adalah respons tubuh yang sifatnya non spesifik terhadap setiap tuntutan beban atasnya (stressor psikososial). Gejala stres didominasi oleh keluhan-keluhan somatik, seperti sakit kepala, sakit perut, penyakit kulit, dan ketegangan otot.

Berdasarkan uraian di atas, dapat disimpulkan bahwa stres adalah sebuah keadaan yang dialami individu ketika ada sebuah tekanan atau ketidaksesuaian antara tuntutan-tuntutan yang diterima dan kemampuan untuk mengatasinya, sehingga menuntut individu untuk dapat beradaptasi atau menyesuaikan diri dengan keadaan tersebut.

Menurut Marsella dkk (2006), sumber stres yang paling umum adalah situasional, yang berasal dari lingkungan dan eksternal orang tersebut. Ini mencakup beragam stres, dari suara bising, suhu tinggi untuk bekerja sampai terlalu banyak bekerja. Namun, ada juga sumber stres internal, yaitu tekanan emosional, krisis eksistensial, pribadi yang cacat dan kelemahan serta masyarakat yang stres dan bencana alam. Boyce (2006) menambahkan bahwa stres pada polisi dapat berasal dari satu atau lebih sumber dan dengan cara yang berbeda-beda, antara lain kondisi tempat kerja polisi yang penuh dengan stres, kebijakan dan administrasi di departemen kepolisian, stres ekstrenal dan internal.

Berdasarkan hal di atas, dapat diketahui bahwa sumber-sumber stres dapat berupa faktor psikologis seperti tekanan emosional, krisis eksistensial, pribadi yang cacat dan kelemahan, dan faktor lingkungan seperti masyarakat yang stres dan bencana alam. Sedangkan sumber stres bagi polisi adalah 
kondisi tempat kerja polisi yang penuh dengan stres, kebijakan dan administrasi di departemen kepolisian, stres ekstrenal dan internal.

Menurut Nevid dkk (2002), faktorfaktor psikologis yang dapat mengurangi stres antara lain adalah cara coping stres, harapan akan keyakinan diri, ketahanan psikologis, optimisme, dukungan sosial, dan identitas etnik. Sedangkan gejala-gejala stres menurut Hariharan dan Rath (2008) terbagi menjadi beberapa bagian, yaitu gejala fisik, intelektual, emosional dan perilaku. Sementara Boyce (2006) menjelaskan bahwa ada beberapa gejala stres pada polisi, yaitu:

a. Gangguan tidur, terutama insomnia dan mimpi buruk

b. Depresi, kecemasan, paranoia, ketakutan, dan panik adalah reaksi dari petugas yang sedang stres

c. Penyalahgunaan zat

d. Terjadinya penyakit fisik seperti sakit kepala, perut, masalah usus, dan penyakit kulit

e. Sinisme

Diener dan Scollon (2003) menjelaskan bahwa kesejahteraan subjektif adalah evaluasi subjektif orang tentang hidup mereka, dan mencakup konsep-konsep seperti kepuasan hidup, emosi yang menyenangkan, perasaan bermakna, kepuasan dalam bidang seperti perkawinan dan pekerjaan, dan rendahnya tingkat emosi yang tidak menyenangkan. Diener dkk (Lever, 2004) menyatakan bahwa kesejahteraan subjektif merupakan kombinasi dari afeksi-afeksi positif dan kepuasan hidup. Sedangkan Diener dan Lucas (Compton, 2005) menyatakan bahwa individu yang memiliki tingkatan kesejahteraan subjektif yang tinggi, akan menunjukkan perasaan yang sangat bahagia, sangat puas dengan hidupnya dan punya pengalaman kecemasan yang rendah.

Berdasarkan hal di atas dapat disimpulkan bahwa kesejahteraan subjektif adalah evaluasi seseorang tentang hidup mereka, termasuk penilaian kognitif terhadap kepuasan dan kebahagiaan hidupnya serta evaluasi afektif dari mood dan emosi-emosi yang positif dan menyenangkan.

Menurut Compton (2005), ada tiga komponen dalam kesejahteraan subjektif, yaitu kebahagiaan, kepuasan hidup dan rendahnya kecemasan. Sementara menurut
Day, Rode, Mooney dan Near (2005), di seluruh publikasi ganda, Diener dan rekan telah mengemukakan bahwa kesejahteraan subjektif adalah konsep multidimensi yang terdiri dari tiga komponen yang terpisah, yaitu :

a. Pengaruh adanya perasaan yang positif

b. Kurangnya pengaruh perasaan yang negatif, dan

c. Evaluasi kognitif dari orang lain terhadap keadaan hidup mereka

Dengan demikian dapat dikatakan bahwa seseorang yang memiliki kesejahteraan subjektif tinggi apabila mereka mengatakan bahwa mereka merasa sangat bahagia, sangat puas dengan hidupnya dan punya pengalaman emosi cemas yang rendah .

Studi kontemporer yang menelusuri penyebab, prediktor dan akibat dari kebahagiaan dan kepuasan hidup disebut studi mengenai kesejahteraan subjektif. Para peneliti di bidang psikologi cenderung menyusun kesejahteraan subjektif berdasarkan nilai pada dua variabel utama, yaitu kebahagiaan dan kepuasan hidup. Penelusuran kebahagiaan dan kepuasan hidup telah memunculkan sejumlah variabel yang dapat dipercaya mengenai kebahagiaan dan kepuasan hidup. Ada enam variabel inti untuk memprediksikan kebahagiaan dan kepuasan hidup paling tidak di budaya Barat dari Argyle, Myers, Diener dkk (Compton, 2005), yaitu harga diri yang positif, rasa tentang pengendalian yang dapat diterima, sifat ektrovert, optimisme, hubungan sosial yang positif, pemahaman tentang arti dan tujuan. Sebagai tambahan variabel, yaitu komponen ketiga dari kesejahteraan subjektif adalah rendahnya laporan diri tentang kecemasan yang dirasakan.

Menurut Diener dan Scollon (2003), ada beberapa faktor-faktor yang mempengaruhi kesejahteraan subjektif, yaitu tujuan, temperamen dan kepribadian, kualitas hubungan sosial, pemenuhan kebutuhan dasar, kesehatan, demografis, sumber daya, budaya, pendapatan dan standar perbandingan.

Pargament dkk (1998) menemukan bahwa koping religius merupakan varian unik yang signifikan dalam memprediksi kesejahteraan di luar coping non religius. Selain itu, menurut Pargament dkk (Ward, 2010), pengukuran koping religius telah terbukti sebagai prediktor yang lebih kuat dalam menghadapi situasi yang penuh stres 
(misalnya, frekuensi kehadiran ibadah, frekuensi doa dll) atau bahkan orientasi agama. Sementara menurut Pargament (Fabricatore dkk, 2004), koping religius adalah satu kerangka yang didasarkan pada pendekatan individu dalam pemecahan masalah dalam konteks hubungan dengan Tuhan.

Berdasarkan hal di atas dapat disimpulkan bahwa koping religius adalah suatu proses multidimensional untuk mengelola, mengubah, atau menguasai situasi, mengatur respon emosional, atau kombinasi dari perilaku tersebut dengan menggabungkan sumber daya rohani (baik pribadi atau sosial), proses penilaian yang mengambil makna suci, atau hasil pemilihan coping yang mengakui pencarian kesucian dari ajaran agama yang dianutnya.

Konsep awal Pargament (1997) tentang koping religius sebagian besar difokuskan pada tiga gaya yang berbeda, yaitu gaya mengarahkan diri (The Self-directing style), gaya menunda (The Deferring style) dan gaya kolaboratif (The Collaborative style). Sementara Wong-McDonald (Maynard dkk, 2001) telah mengusulkan gaya koping religius yang keempat, yaitu pasrah (surrender), di mana individu bekerja sama dengan Tuhan dimana petunjuk berharga dari Tuhan diatas segalanya. Kemudian Pargament, Koenig dan Perez (2000) mengidentifikasi lima fungsi kunci keagamaan sebagai tujuan penelitiannya. Setelah itu, metode koping religius didefinisikan berdasarkan lima fungsi dasar agama, yaitu :

a. Metode koping religius dalam mencari $\mathrm{m} \quad \mathrm{a} \quad \mathrm{k} \quad \mathrm{n} \quad \mathrm{a}$

b. Metode koping religius untuk $\mathrm{m}$ e $\mathrm{nd}$ a $\mathrm{p}$ a $\mathrm{t} \mathrm{k}$ a $\mathrm{n}$ k o n t r o

c. Metode koping religius untuk mendapatkan kenyamanan dan mencapai $\mathrm{k}$ e d e k a ta n e n g a A $11 \mathrm{ah}$

d. Metode koping religius dalam menjalin keintiman dengan sosial dan kedekatan $\mathrm{d}$ e $\mathrm{n} \mathrm{g}$ a $\mathrm{n}$

$\mathrm{T} \mathrm{u} \mathrm{h}$ a $\mathrm{n}$

e. Metode koping religius dalam melayani $\mathrm{p}$ e $\mathrm{r} \mathrm{u}$ b a h a $\mathrm{k}$ e h i d u a $\mathrm{n}$ Berdasarkan hal di atas dapat disimpulkan bahwa konsep-konsep koping religius pada awalnya difokuskan pada tiga gaya yang berbeda, namun setelah itu dilakukan pengembangan lebih lanjut.
Pengukuran lebih lanjut mengenai koping religius didasarkan pada lima fungsi dasar agama, yang kemudian ditetapkan sebagai metode koping religius, yaitu metode koping religius mencari makna, mendapatkan kontrol, mendapatkan kenyamanan dan mencapai kedekatan dengan Allah, menjalin keintiman dengan sosial dan kedekatan dengan Tuhan dan melayani perubahan kehidupan.

Menurut Marsella dkk (2006), ada beberapa alat pengukuran koping religius, yaitu The Negative Religious Coping Scale, The RCOPE dan Brief RCOPE serta The Hindu Religious Coping Scale. Selain itu, ada juga skala koping religius lainnya, yaitu Religious Coping Activities Scale (RCAS) dan Religious Coping Scale (RCOPE).

Berdasarkan hal di atas, dapat diketahui ada beberapa alat pengukuran koping religius, yaitu The Negative Religious Coping Scale, The RCOPE dan Brief RCOPE, The Hindu Religious Coping Scale, Religious Coping Activities Scale (RCAS) dan Religious Coping Scale (RCOPE) yang dikembangkan dan digunakan pada penduduk Iran. Namun pengukuran yang digunakan dalam penelitian ini mengacu pada Religious Coping Scale (RCOPE) yang dikembangkan oleh Aflakseir dan Coleman (2009).

Menurut Harrison (Marsella dkk, 2006), selama enam tahun terakhir sejumlah besar penelitian tentang koping religius telah berfokus pada hasil, dan lebih tepatnya, hubungan dengan berbagai bentuk kesehatan mental dan fisik. Secara keseluruhan, hasil ini cenderung menunjuk pada fakta bahwa koping religius merupakan cara yang menguntungkan dalam menghadapi stres yang luar biasa dalam kehidupan sehari-hari. Selain itu, menurut Zinnbauer (Marsella dkk, 2006), semua perilaku manusia, termasuk koping religius menjalankan keseluruhan antara yang baik dan yang jahat, fungsional dan menyesuaikan diri, pantas atau tidak pantas, mulia dan jahat. Para peneliti kesehatan harus mencatat fakta bahwa bagi banyak individu religius dan spiritual, sering dianggap penting dalam pencapaian kesehatan fisik dan psikologis, untuk itu koping religius harus dilihat secara kontekstual. 


\section{METODE PENELITIAN}

\section{Rancangan Penelitian}

Penelitian ini menggunakan pendekatan kuantitatif yaitu dengan menggunakan analisis statistik. Pendekatan analisis dilakukan dengan teknik korelasi parsial dan diolah dengan menggunakan program SPSS 16.0 untuk melihat bagaimana peranan koping religius dan kesejahteraan subjektif terhadap stres.

\section{Populasi dan Sampel Penelitian}

Populasi dalam penelitian ini berjumlah 94 orang Polisi anggota Sabhara di Polres Kebumen. Namun yang diizinkan untuk digunakan dalam penelitian hanyalah anggota yang berpangkat Brigadir, Briptu dan Bripda. Untuk uji coba alat ukur, peneliti menggunakan 10 orang anggota polisi di satuan Sabhara berpangkat Bripda, 17 orang anggota Sabhara berpangkat Briptu dan 4 orang anggota Sabhara berpangkat Brigadir, sehingga jumlah subjek untuk uji coba alat ukur berjumlah 31 orang. Sementara subjek penelitian berjumlah 55 orang anggota polisi berpangkat Bripda.

\section{Alat Ukur}

Instrumen penelitian yang digunakan dalam penelitian ini menggunakan metode skala psikologis dengan tiga macam skala: 1$)$ Skala stres 2) Skala koping religius 3) Skala kesejahteraan subjektif.

Skala koping religius diadaptasi dari RCOPE bagi umat Islam di Iran, namun tetap mengadaptasi dari skala Pargament (Aflakseir \& Coleman, 2009). Sedangkan skala kesejahteraan subjektif dan skala stres dibuat sendiri oleh peneliti berdasarkan indikator dan gejala dari masing-masing variabel.

\section{HASIL PENELITIAN}

\section{Deskripsi Subjek}

Subjek yang dikenai penelitian ini berjumlah 55 orang yang berasal dari Polres Kebumen. Adapun sebaran subjek berdasarkan kategori usia dapat dilihat dalam tabel 1 dibawah ini :
Tabel 1 Deskripsi Usia Subjek Penelitian

\begin{tabular}{|c|c|c|}
\hline Usia & Jumlah & Presentase \\
\hline 20 tahun & 1 & $1,8 \%$ \\
\hline 21 tahun & 13 & $23,6 \%$ \\
\hline 22 tahun & 23 & $41,8 \%$ \\
\hline 23 tahun & 17 & $30,9 \%$ \\
\hline 24 tahun & 1 & $1,8 \%$ \\
\hline Total & $\mathbf{5 5}$ & $\mathbf{1 0 0 \%}$ \\
\hline
\end{tabular}

Berdasarkan usia subjek, rata-rata usia subjek adalah 22 tahun (41,8\%), 23 tahun (30,9\%), 21 tahun $(23,6 \%), 20$ tahun $(1,8 \%)$ dan 24 tahun $(1,8 \%)$.

Ditinjau dari kategori status pernikahan, seluruh subjek penelitian masih berstatus lajang (belum menikah) yaitu sebanyak 55 orang (100\%). Adapun sebaran subjek berdasarkan status pernikahan dapat dilihat dalam tabel 2.

Tabel 2Deskripsi Status Pernikahan Subjek Penelitian

\begin{tabular}{|c|c|c|}
\hline Status & Jumlah & Presentase \\
\hline Lajang & 55 & $100 \%$ \\
\hline Menikah & 0 & $0 \%$ \\
\hline Total & $\mathbf{5 5}$ & $\mathbf{1 0 0 \%}$ \\
\hline
\end{tabular}

Berdasarkan kategori lamanya masa kerja, anggota Sabhara di Polres Kebumen yang bekerja selama 1 tahun sebanyak 10 orang $(18,2 \%), 2$ tahun sebanyak 30 orang $(54,5 \%)$ dan 3 tahun sebanyak 15 orang $(27,3 \%)$. Adapun sebaran subjek berdasarkan lamanya kerja dapat dilihat dalam tabel 3 .

Tabel 3 Deskripsi Lamanya Masa Kerja Subjek Penelitian

\begin{tabular}{|c|c|c|}
\hline Lama Kerja & Jumlah & Presentase \\
\hline 1 tahun & 10 & $18,2 \%$ \\
\hline 2 tahun & 30 & $54,5 \%$ \\
\hline 3 tahun & 15 & $27,3 \%$ \\
\hline Total & $\mathbf{5 5}$ & $\mathbf{1 0 0 \%}$ \\
\hline
\end{tabular}

\section{Hasil Uji Asumsi}

\section{a. Uji Normalitas}

Berdasarkan hasil uji normalitas yang dilakukan dapat diketahui bahwa sebaran skor pada skala stres, koping religius dan kesejahteraan subjektif memiliki sebaran normal. Rangkuman hasil uji normalitas dapat dilihat dalam tabel dibawah. 
Tabel 4

Rangkuman Hasil Uji Normalitas Untuk Tiap Variabel

\begin{tabular}{|c|c|c|c|}
\hline Variabel & K-SZ & Sig. & Ket. \\
\hline Stres & 1,007 & 0,262 & Normal \\
\hline Kesejahteraan Subjektif & 0,602 & 0,862 & Normal \\
\hline Koping Religius & 1,005 & 0,264 & Normal \\
\hline
\end{tabular}

a. Uji Linearitas

Uji linieritas dilakukan dengan menggunakan program SPSS (Statistic Program For Social Science) 16.00 for Windows dengan teknik Compare Means. Kaidah yang digunakan adalah jika nilai signifikansi $\mathrm{p} \leq 0,05$, maka hubungan kedua variabel linier dan sebaliknya jika nilai signifikansi $\mathrm{p}>0,05$, maka hubungan kedua variabel tidak linier. Nilai signifikansi dilihat pada bagian linearity pada tabel Anova. Rangkuman hasil analisis linearitas dapat dilihat pada tabel di bawah ini.

Tabel 5 Rangkuman Hasil Analisis Linearitas

\begin{tabular}{|l|c|c|c|}
\hline \multirow{2}{*}{ Variabel } & \multicolumn{2}{|c|}{ Linearity } & \multirow{2}{*}{ Ket. } \\
\cline { 2 - 3 } & F & Sig. & \\
\hline Stres - Koping religious & 27,119 & 0,000 & Linear \\
\hline Stres - Kesejahteraan subjektif & 17,327 & 0,000 & Linear \\
\hline
\end{tabular}

Berdasarkan hasil uji linieritas yang dilakukan dapat diketahui bahwa ada hubungan yang linier antara variabel stres, koping religius dan kesejahteraan subjektif

\section{Hasil Uji Hipotesis}

Uji Hipotesis Mayor. Untuk mengetahui adanya peranan variabel koping religius, kesejahteraan subjektif terhadap stres, maka dilakukan uji analisis korelasi parsial dengan menggunakan program komputer SPSS (Statistic Program For Social Science) 16.00 for Windows. Koefesien korelasi antara stres dengan koping religius sebesar $-0,517$ dengan $\mathrm{p}=$ $0,000(\mathrm{p}<0,01)$, sementara koefesien korelasi dengan kesejahteraan subjektif sebesar $-0,309$ dengan $\mathrm{p}=0,022(\mathrm{p}>0,01)$.

Uji Hipotesis Minor Koping Religius dan Stres. Hasil analisis korelasi parsial menunjukkan bahwa besarnya koefesien korelasi koping religius dengan stres sebelum kesejahteraan subjektif dikontrol sebesar - 0,517. Sedangkan koefesien korelasi antara koping religius dengan stres setelah kesejahteraan subjektif dikontrol sebesar $-0,437$ dengan nilai $p=0,001(\mathrm{p}<$ $0,01)$.

Uji Hipotesis Kesejahteraan Subjektif dan Stres. Hasil analisis korelasi parsial menunjukkan besarnya koefesien korelasi kesejahteraan subjektif dengan stres sebelum koping religius dikontrol sebesar0,309. Namun, apabila koping religius dikontrol, maka koefesien korelasi antara kesejahteraan subjektif dengan stres sebesar $-0,028$ dengan nilai $p=0,839(p$ $>0,05)$.

Hasil Analisis Tambahan. Dilakukan pada gejala-gejala stres. Hasil analisis menunjukkan bahwa gejala emosional paling banyak muncul pada anggota Sabhara Polres Kebumen dibandingkan gejala-gejala yang lain $($ Mean $=31,53)$. Setelah gejala emosional, gejala yang juga paling banyak muncul adalah perilaku $($ Mean $=26,51)$, selanjutnya fisik (Mean $=23,04)$ dan intelektual $($ Mean $=22,35)$.

Hasil analisis tambahan menunjukkan bahwa prediktor kesejahteraan subjektif yang paling kuat dimiliki oleh anggota Sabhara Polres Kebumen adalah optimisme $($ Mean $=24,91)$. Prediktor yang selanjutnya adalah hubungan yang positif (Mean = 21,27), pemahaman tentang arti dan tujuan $($ Mean $=19,60)$, harga diri $($ Mean $=19,35)$, Sikap ekstrovert $($ Mean $=18,75)$, rendahnya kecemasan (Mean $=15,29)$ dan pengendalian yang diterima $($ Mean $=14,91)$.

Hasil analisis tambahan menunjukkan bahwa metode koping religius yang paling banyak digunakan oleh anggota Sabhara Polres Kebumen adalah aktif koping religius $($ Mean $=32,91)$. Metode yang selanjutnya adalah praktek koping religius (Mean = 20,35), selanjutnya positif koping religius $($ Mean $=17,95)$ dan penilaian kebajikan $($ Mean $=13,98)$.

\section{PEMBAHASAN}

Penelitian ini bertujuan untuk mengetahui peranan koping religius dan kesejahteraan subjektif terhadap stres pada anggota bintara polisi di Polres Kebumen. Hasil analisis korelasi parsial menunjukkan adanya korelasi negatif yang sangat signifikan antara koping religius dengan 
stres apabila variabel kesejahteraan subjektif dikontrol. Jadi hasil analisis data penelitian menunjukkan terdapat korelasi negatif yang sangat signifikan antara koping religius dengan stres sebelum dan sesudah variabel kesejahteraan subjektif dikontrol. Dengan demikian dapat ditarik kesimpulan, bahwa penggunaan koping religius dapat menurunkan tingkat stres. Semakin tinggi koping religius, maka semakin rendah tingkat stres dan sebaliknya semakin rendah koping religius, maka semakin tinggi tingkat stres seseorang.

Hasil penelitian ini membuktikan bahwa penggunaan koping religius adalah salah satu cara yang terbaik untuk menurunkan tingkat stres seseorang. Hal ini senada dengan yang diungkapkan oleh Pargament dkk (Ward, 2010), bahwa pengukuran koping religius telah terbukti sebagai prediktor yang lebih kuat dalam menghadapi situasi yang penuh stres daripada yang umum. Sementara menurut Harrison (Marsella dkk, 2006), selama enam tahun terakhir sejumlah besar penelitian tentang koping religius telah berfokus pada hasil, dan lebih tepatnya, hubungan dengan berbagai bentuk kesehatan mental dan fisik. Secara keseluruhan, hasil ini cenderung menunjuk pada fakta bahwa koping religius merupakan cara yang menguntungkan dalam menghadapi stres yang luar biasa dalam kehidupan sehari-hari.

Penelitian Pargament dkk (1998) tentang agama dan orientasi strategi koping menemukan strategi yang digunakan orang untuk menghadapi stres dan kesulitan dalam hidup. Orang yang religius dan memiliki strategi koping akan mampu menghadapi stres ataupun depresi dalam hidupnya. Harris dkk dan Pargament (dalam Marsella dkk, 2006) menambahkan bahwa koping religius benar-benar mencerminkan berbagai strategi yang mencakup seluruh pilihan koping. Apa yang tampaknya membedakan koping religius adalah penggabungan sumber daya rohani (baik pribadi atau sosial), proses penilaian yang mengambil makna suci, atau hasil pemilihan koping yang mengakui pencarian kesucian.

Hasil kategorisasi menunjukkan bahwa tingkat koping religius anggota
Sabhara Polres Kebumen termasuk sedang yaitu sebanyak 28 orang $(50,9 \%)$, rendah sebanyak 26 orang $(47,3 \%)$ dan tinggi hanya 1 orang $(1,8 \%)$. Sementara hasil analisis tambahan menunjukkan bahwa metode koping religius yang paling banyak digunakan oleh anggota Sabhara Polres Kebumen adalah aktif koping religius (Mean $=32,91)$, praktek koping religius $($ Mean $=20,35)$, selanjutnya positif koping religius $($ Mean $=17,95)$ dan penilaian kebajikan $($ Mean $=13,98)$.

Studi cross-sectional yang dilakukan Day dan Pargament (Ward, 2010) telah menemukan bahwa strategi koping religius yang positif dikaitkan dengan peningkatan kesejahteraan. Sementara menurut Harrison dkk (dalam Marsella dkk, 2006), penggunaan strategi positif koping religius, seperti mencari dan memberikan dukungan spiritual, penilaian kembali dari situasi stres, dan gaya kolaboratif koping religius, telah terbukti berhubungan dengan kesehatan mental yang lebih baik, sedangkan strategi koping religius negatif, seperti gaya menunda, penilaian kembali dari suatu peristiwa negatif, dan ketidakpuasan spiritual, telah dihubungkan dengan adanya peningkatan gejala depresi.

Subjek yang dikenai penelitian ini berjumlah 55 orang yang berasal dari satuan Sabhara Polres Kebumen. Berdasarkan hasil kategorisasi dapat diketahui bahwa tingkat stres subjek termasuk rendah yaitu sebanyak 31 orang $(56,4 \%)$ dan tingkat stres sedang sebanyak 24 orang $(43,6 \%)$. Hal ini terjadi karena rata-rata usia anggota Sabhara di polres Kebumen tergolong masih muda yaitu 22 tahun (41,8\%), 23 tahun (31\%), 21 tahun $(23,6 \%), 20$ tahun $(1,8 \%)$ dan 24 tahun $(1,8 \%)$. Dengan demikian subjek penelitian yang berpangkat Bripda sebagian besar berusia 22 tahun. Sementara berdasarkan kategori lamanya masa kerja, anggota Sabhara di Polres Kebumen yang bekerja selama 1 tahun sebanyak 10 orang $(18,2 \%), 2$ tahun sebanyak 30 orang $(54,5 \%)$ dan 3 tahun sebanyak 15 orang $(27,3 \%)$. Apabila dilihat dari lamanya masa kerja, sebagian besar anggota polisi di Polres Kebumen memiliki masa kerja yang tergolong baru yaitu 2 tahun. 
Hasil penelitian Deschamps dkk (2003) menunjukkan bahwa anggota polisi yang berusia 30 tahun ke atas memiliki tingkat stres yang lebih tinggi dari anggota polisi yang lebih muda. Hal ini karena beban kerja yang berhubungan langsung dengan birokrasi organisasi semakin meningkat, dimana mereka harus mengawasi bawahannya dan melapor pada atasannya. Dengan kata lain, tanggung jawab yang dimiliki anggota polisi yang berusia 30 tahun ke atas lebih banyak daripada anggota polisi yang lebih muda.

Sementara hasil analisis tambahan yang dilakukan pada gejala-gejala stres menunjukkan bahwa gejala emosional paling banyak muncul pada anggota Sabhara Polres Kebumen dibandingkan gejala-gejala yang lain (Mean =31,53). Menurut Boyce (2006), masalah emosional yang dihadapi petugas sering berasal dari stresor pekerjaan polisi yang lain dan masalah keluarga. Perkembangan masalah sikap, masalah perilaku, keintiman dan masalah dalam hubungan membuat stres dan mengganggu kinerja petugas itu. Perasaan bersalah, kecemasan dan ketakutan, masalah tidur seperti mimpi buruk dan insomnia juga merupakan sumber stres bagi petugas. Setelah gejala emosional, gejala yang juga paling banyak muncul adalah perilaku (Mean $=26,51)$, selanjutnya fisik $($ Mean $=23,04)$ dan intelektual $($ Mean $=22,35)$.

Hasil analisis korelasi parsial selanjutnya menyatakan bahwa tidak ada korelasi antara kesejahteraan subjektif dengan stres apabila variabel koping religious dikontrol. Adanya hubungan antara kesejahteraan subjektif dengan stres sebelum dikontrol lebih disebabkan oleh pengaruh variabel koping religius. Hal ini sesuai dengan hasil penelitian Fabricatore dkk (2004) yang menemukan bahwa kolaborasi koping religius memediasi hubungan antara religiusitas, kesejahteraan dan distres. Sementara penelitian Karlsen, Dybdahl dan Vitterso (2006) menggambarkan bagaimana koping, trauma dan makna positif memberi pengaruh pada stres dan kesejahteraan subjektif pada veteran.

Hasil penelitian Ng dkk (2008) menemukan bahwa stres menunjukkan hubungan negatif yang lemah dengan kesejahteraan daripada dengan perasaan negatif. Stres adalah suatu keadaan yang dapat mengurangi kesejahteraan seseorang. Jika stres pada waktu tertentu dapat menyebabkan stres kronis, mengurangi kualitas hidup, dan dengan demikian juga mengurangi kesejahteraan. Menurut Diener dan Lucas (Compton, 2005), individu yang memiliki tingkatan kesejahteraan subjektif yang tinggi, akan menunjukkan perasaan yang sangat bahagia, sangat puas dengan hidupnya dan punya pengalaman kecemasan (emosi negatif) yang rendah.

Sedangkan hasil kategorisasi tingkat kesejahteraan subjektif menunjukkan bahwa tingkat anggota Sabhara Polres Kebumen termasuk sedang yaitu sebanyak 45 orang $(81,8 \%)$ dan rendah sebanyak 10 orang $(18,2 \%)$. Hasil analisis tambahan menunjukkan bahwa prediktor kesejahteraan subjektif yang paling kuat dimiliki oleh anggota Sabhara Polres Kebumen adalah optimisme $($ Mean $=24,91)$. Menurut Diener dkk (Compton, 2005), pada umumnya, orang yang lebih optimis tentang masa depannya dilaporkan merasa lebih bahagia dan puas atas hidupnya, begitupun dengan anggota Sabhara di Polres Kebumen yang memiliki nilai optimisme yang besar. Prediktor kesejahteraan subjektif yang selanjutnya memiliki nilai rata-rata yang cukup besar adalah hubungan yang positif (Mean = 21,27), pemahaman tentang arti dan tujuan $($ Mean $=19,60)$, harga diri $($ Mean $=19,35)$, sikap ekstrovert $($ Mean $=18,75)$, rendahnya kecemasan $($ Mean $=15,29)$ dan pengendalian yang diterima $($ Mean $=14,91)$.

Walaupun seluruh anggota Sabhara Polres Kebumen masih berstatus lajang (belum menikah) yaitu sebanyak 55 orang $(100 \%)$, namun ternyata hal tersebut tidak memengaruhi kesejahteraan subjektif mereka. Hal ini karena selain mereka memiliki sikap optimisme yang besar, anggota Sabhara ini pun menunjukkan nilai rata-rata hubungan positif yang juga cukup besar. Pada umumnya, ada dua aspek yang berkaitan dengan hubungan sosial yang positif, yaitu keintiman emosional dan kontak sosial. Hasil penelitian Ed Diener dan Martin Seligman (Compton, 2005 
menunjukkan bahwa kelompok yang paling bahagia memiliki kehidupan sosial yang luas. Dengan demikian, peneliti menyimpulkan bahwa walaupun seluruh anggota Sabhara yang ada dalam penelitian ini belum menikah, namun hal tersebut tidak terlalu memengaruhi kesejahteraan subjektif mereka. Hal ini terjadi karena sebagian besar dari anggota Sabhara tersebut memiliki hubungan sosial yang cukup baik dengan lingkungannya.

Selain itu, menurut Nevid dkk (2002), faktor-faktor psikologis yang dapat mengurangi stres antara lain adalah cara koping stres, harapan akan efikasi diri, ketahanan psikologis, optimisme, dukungan sosial, dan identitas etnik. Dengan demikian dapat peneliti simpulkan bahwa rendahnya tingkat stres pada anggota bintara polisi di Polres Kebumen karena ada beberapa faktorfaktor psikologis yang telah mereka gunakan untuk mengurangi stres antara lain adalah cara koping stres yaitu dengan banyak menggunakan aktif koping religius $($ Mean $=32,91)$ dan praktek koping religius $($ Mean $=20,35)$. Anggota polisi di Polres Kebumen juga memiliki sikap optimisme yang tinggi $($ Mean $=24,91)$ dan dukungan sosial / hubungan positif $($ Mean $=21,27)$ yang baik dengan lingkungannya, sehingga pada akhirnya kesejateraan subjektif yang mereka miliki cukup baik.

\section{SIMPULAN DAN SARAN}

\section{Simpulan}

Koping religius dan kesejahteraan subjektif memiliki peran terhadap stres pada anggota Bintara polisi di Polres Kebumen. Anggota Bintara polisi yang menggunakan koping religius aktif dan menjalankan praktek koping religius, memiliki tingkat stres yang rendah. Selain itu, tingginya tingkat optimisme dan baiknya hubungan positif yang dimiliki oleh anggota Bintara polisi di Polres Kebumen menyebabkan kesejahteraan subjektif mereka cukup baik, dan pada akhirnya tingkat stres yang mereka miliki juga rendah.

Ada hubungan yang sangat signifikan antara koping religius dan stres apabila variabel kesejahteraan subjektif dikontrol. Dengan demikian dapat ditarik kesimpulan, bahwa untuk menurunkan stres dengan cara meningkatkan koping religius. Semakin tinggi penggunaan koping religius, maka semakin rendah tingkat stres.

Tidak ada hubungan antara kesejahteraan subjektif dengan stres apabila variabel koping religius dikontrol. Adanya hubungan antara kesejahteraan subjektif dengan stres sebelum dikontrol lebih disebabkan oleh adanya pengaruh variabel koping religius.

\section{Saran}

\section{Bagi Subjek Penelitian}

Tidak dapat dipungkiri bahwa setiap orang dalam hidupnya pernah mengalami stres. Untuk itu penggunaan agama sebagai strategi koping adalah salah cara yang paling tepat untuk mengurangi stres. Anggota polisi khususnya di satuan Sabhara hendaknya memurnikan kembali ajaran agamanya dengan belajar secara utuh dan menyeluruh tentang pokok-pokok ajaran agamanya, baik secara sendiri-sendiri ataupun melalui wadah yang telah disediakan di Polres Kebumen yaitu Binrohtal (pembinaan rohani dan mental). Pada akhirnya, penggunaan koping religius diharapkan dapat meningkatkan kebahagiaan, kepuasaan hidup dan menurunkan kecemasan yang sedang mereka hadapi.

\section{Bagi Kepolisian Republik Indonesia}

Perlu ditingkatkan kembali kegiatan Binrohtal (pembinaan rohani dan mental) dikalangan anggota polisi. Pembinaan tersebut hendaknya tidak saja hanya berupa pengajian atau ceramah, namun alangkah lebih baik apabila ditambahkan dengan unsur-unsur pendekatan yang bersifat psikologis terhadap anggotanya. Seperti yang diungkapkan oleh Nevid dkk (2002) yang menyatakan bahwa ada beberapa faktor-faktor psikologis yang dapat mengurangi stres antara lain adalah 
cara koping stres, harapan akan efikasi diri, ketahanan psikologis, optimisme, dukungan sosial, dan identitas etnik. Oleh karena itu, pihak organisasi hendaknya dapat memberikan kegiatan yang disesuikan dengan kebutuhan anggota Polisi untuk mengurangi stresnya. Misalnya melakukan pelatihan manajemen stres berpendekatan koping religius atau dapat juga pelatihan ketahanan psikologis dan lain-lain. Kegiatan tidak hanya dilakukan sampai pelatihan saja, namun hendaknya ada monitoring terhadap hasil pelatihan tersebut, sehingga dapat diketahui apakah pemberian pelatihan tersebut bermanfaat atau tidak terhadap anggota polisi. Dengan demikian, apabila ternyata hasilnya bermanfaat hal ini dapat memengaruhi kesejahteraan subjektif anggotanya. Studi crosssectional yang dilakukan Day dan Pargament (Ward, 2010) telah menemukan bahwa strategi koping religius yang positif dikaitkan dengan peningkatan kesejahteraan.

\section{Bagi Peneliti Selanjutnya}

Bagi peneliti selanjutnya yang berminat dengan tema yang sama, disarankan untuk meminimalkan kelemahan-kelemahan penelitian ini, yaitu memperhatikan faktor-faktor yang belum atau tidak terungkap dalam penelitian ini yang sekiranya dapat memengaruhi stres bagi subjek penelitian.

\section{DAFTAR PUSTAKA}

Aflakseir, A., and Coleman, P.G. (2009). The influence of religious coping on the mental health of disabled Iranian war veterans. Mental Health, Religion and Culture, 12 (2), 175-190.

Ano,G.G., and Vasconcelles, E.B. 2005. Religious Coping and Psychological Adjustment to Stress: A MetaAnalysis. Journal of Clinical
Psychology, 61(4), 461-480.

Berg, A.M.,Hem., E., Lau, B., and Ekeberg, O. 2006. An exploration of job stress and health in the Norwegian police service: a cross sectional study. Journal of Occupational Medicine and Toxicology, $1: 26$.

Boyce, J. (2006). Police Officers Under Stress. System School of Law Enforcement Supervision. Arkansas : Criminal Justice Institute University.

Compton,W.C. (2005). An Introduction to Postive Psychology. United States of America: Thompson Learning, Inc.

Constant, Terry. (1991). Not So Obvious Police Stress. Didownload dari http://www.tearsofacop.com/police/arti cles/constant.html. Diakses pada tanggal 27 September 2010.

Day, M.L.A., Rode, J.C., Mooney, C.H., and Near, J.P. (2005). The Subjective Well-Being Construct: A Test of Its Convergent, Discriminant, and Factorial Validity. Social Indicators Research, 74,(3),445-476.

Deschamps, F., Badinier, I.P., Marchand, A.C., and Merle, C. 2003. Source and Assesment of Occupational Stress in The Police. Journal of Occupational Health, 45 :358-364.

Diener,E., Oishi, S., and Lucas, R.E. (2003). Personality, Culture and Subjective Well Being : Emotional and Cognitive Evaluation of Life. Annual Review of Psychology, 54 : 403-425.

Diener, E., and Scollon, C. 2003. Subjective Well-Being Is Desirable, But Not the Summum Bonum. Paper to be delivered at the University of Minnesota Interdisciplinary Workshop on Well-Being, October 23 - 25, 2003, Minneapolis. Amerika : Department of Psychology University of Illinois. 
M., and Gilner, F. H. (2004). Stress, religion, and mental health: Religious coping in mediating and moderating roles. The International Journal for the Psychology of Religion, 14, 91-108.

Federal Anti-Terrorism Supplemental Grant. ( 2010$)$. Police Stress.Didownload dari www.traumacenter.org/resources/pdf files/Police Stress.pdf. Diakses pada tanggal 02 des 2010.

Folkman, S., and Moskowitz, J. T. (2000). Positive affect and the other side of coping. American Psychologist, 55(6), 647-654.

Hariharan,M., and Rath, R. (2008). Coping With Life Stress. India : Sage Publications India Pvt Ltd.

Hawari, D. (2008). Al Qur'an : Ilmu Kedokteran Jiwa dan Kesehatan Jiwa. Jakarta : PT. Dana Bhakti Prima Yasa.

Huda, M.N. (2003). The Stress Factor in Policing. Di download dari http://www.thedailystar.net/2003/07/03/ d30703150278.htm. Diakses pada tanggal 27 Agustus 2010.

Karlson, E., Dybdahl, R., \& Vitterso, J. (2006) The Possible Benefitsof Difficulty : How Stress Can Increase and Decrease Subjective Well-Being. Scandinavian Journal of Psychology, 47, 411-417.

Kunarto,, dan Tabah, A. (1995). Polisi : Harapan dan Kenyataan. Klaten : CV. Sahabat.

Lever, J.P. (2004). Poverty and Subjective Well-Being in Mexico. Social Indicators Research, Vol. 68, No. 1, pp. 1-33.

Marsella, A.J., Wong, P.T.P., and Wong, L.C.J. (2006). Handbook of Multicultural Perspectives on Stress and Coping. United States of America: Springer.
Maynard,E.A., Gorsuch, R.L., and Bjorck, J.P. (2001). Religious Coping Style, Concept of God, and Personal Religious Variables in Threat, Loss, and Challenge Situations. Journal for the Scientific Study of Religion, Vol. 40, No. 1, pp. 65-74.

Nevid, J.S., Rathus, S.A., and Greene, B. (2002). Psikologi Abnormal. Jakarta :Penerbit Erlangga.

Ng, W., Diener,E., Aurora, R., and Harter, J. (2008). Affluence, Feelings of Stress, and Well-being. Soc Indic Res DOI 10.1007/s 11205-008-9422-5. Springer Science and Business Media B.V.

Pargament, K. I. (1997). The psychology of religion and coping: Theory, research, and practice. New York: Guilford Press.

Pargament, K. I., Smith, B.W., Koenig, H.G., and Perez, L. 1998. Patterns of positive and negative religious coping with major life stressors. Journalfor the Scientific Study of Religion 37(4): 710-24.

Pargament, K. I., Koenig, H. G., and Perez, L. M. (2000). The many methods of religious coping: Development and initial validation of the RCOPE. Journal of Clinical Psychology, 56, 519-543.

Subiansauri, H.(2010). Masyarakat yang Menggaji Polisi. Di download dari www.komisikepolisianindonesia.com/s econdPg.php?cat...id.. Diakes pada tanggal 18 Februari 2011.

Ward, A.M. (2010). The Relationship Between Religiosity and Religious Coping to Stress Reactivity and Psychological Well-Being. Dissertations. Georgia State University.

Yusuf, M.N.A. 2009. Stres. Di download dari www.metro.polri.web.id. Di akses pada tanggal 27 November 2010. 